\title{
Jarabak 's Cephalometric Analysis of Brazilian Black Patients
}

\author{
Mayury KURAMAE \\ Maria Beatriz Borges de Araújo MAGNANI \\ Eloísa Marcantonio BOECK \\ Adriana Simoni LUCATO \\ Department of Pediatric Denstistry, Orthodontics Area, School of Dentistry of Piracicaba, \\ State University of Campinas, Piracicaba, SP, Brazil
}

\begin{abstract}
The treatment of skeletal disharmonies presents better results when performed during the growth period. The physical changes that occur in every individual express growth, which is ruled by genetic, general and environmental factors. In order to identify such disharmonies and hence concentrate the clinical actions during treatment and influence facial growth, cephalometrics appears as a useful a diagnostic tool for identifying facial growth patterns or growth direction. Jarabak's cephalometric analysis is used to assess facial growth pattern of subjects with normal occlusion or malocclusions. The purpose of this study was to obtain mean values for cephalometric measurements from Jarabak’s cephalometric analyses of black Brazilian subjects resident in the city of Piracicaba, São Paulo state, Brazil and vicinities, who presented Class I molar relationship with normal overjet and overbite, mild or no tooth crowding or spacing, and no history of orthodontic treatment. A sample of 37 stone plaster casts and 37 lateral teleradiographs from both male and female individuals aged 10 to 14 years was evaluated. Data were analyzed statistically by Student's t-test at 5\% significance level. There was no significant differences between genders. The cephalometric measurements obtained in this study were similar to the Jarabak’s standards, except for S-N mean value in females $(66.50 \mathrm{~mm} \pm 3.16)$, which was significantly lower than the standard.
\end{abstract}

Key Words: cephalometrics, Orthodontics, African continental ancestry group.

\section{INTRODUCTION}

Skeletal discrepancies show better results when treated during growth period. Thus, early intervention has become a modality of orthodontic therapy since the 70's. Cephalometric analysis is a useful diagnostic tool to determine facial type and its growth pattern, so that the clinician can determine facial disharmonies in order to centralize therapeutic measures during treatment and modify facial growth.

Jarabak (1) has defined cephalometrics as the science that segments the dentofacial complex in order to assess the relationship among segments and how individual growth increments or their changes can affect the whole complex. Jarabak's cephalometric analysis was based on the investigative studies of Björk (2), which were applied to clinical conditions, making possible to compare variations of shape, size, age, gender and race. Jarabak's cephalometric analysis also considers anteroposterior (Class I, Class II and Class III) and vertical (deep or open bite) intermaxillary relationships, taking as a reference the original structure: the cranial base. It also makes possible to diagnose the main determinant factors.

Given that Jarabak's cephalometric analysis is clinically effective, its application on evaluating anomalies and prognosis is justified and the following aspects should be considered: morphological characteristics, prediction of facial growth pattern, possible reactions to different orthodontic approaches and detection of possible tendencies to functional alterations (3).

The several skeletal malocclusions are defined during growth. The orthodontist who is interested on treating young patients will have to assess every specific 
growth pattern, thus knowing its directions and possibilities. Only after this an orthodontic mechanics will be chosen for better results and with less difficulties.

Jarabak's cephalometric analysis can also predict the results of different orthodontic approaches. The analysis of lines and angles that define this analysis provides the clinician with the skeletal characteristics and, as a result, identification of muscular pattern. These can be directly applied on the selection of orthodontic or orthopedic devices, in such a way that the clinician can be able to evaluate the facial growth response from these therapeutic procedures.

The variety of craniofacial characteristics present in the different racial and ethnic groups have been investigated in several studies (4-14), which mention the adoption of standard normality mean values for each specific group. Thus, each group should be evaluated separately, according to its individual characteristics.

Black subjects have craniofacial characteristics that are distinct from those of other races, especially Caucasians. As the cephalometric analysis routinely used for diagnosis and treatment planning in Orthodontics is generally based on Caucasian cephalometric standards, there has been concern on elaborating a cephalometric analysis more specific to young Brazilian Black patients.

The purpose of this study was to determine mean values of Jarabak's cephalometric analysis for Brazilian Black youngsters with clinically excellent occlusion and to verify the differences between males and females.

\section{MATERIAL AND METHODS}

The sample was formed from the files of the Scientific Documentation Sector of the Postgraduate Course in Orthodontics of the School of Dentistry of Piracicaba, UNICAMP. It comprised 37 lateral teleradiographs and dental casts from 10-14-year-old male $(\mathrm{n}=16)$ and female $(\mathrm{n}=21)$ Brazilian individuals who were descendants from Black parents/grandparents and lived in the city of Piracicaba, SP. The participants have never undergone orthodontic treatment before and presented Class I molar relationship with normal overjet and overbite, mild or no tooth crowding or spacing and ANB ranging from 1 to $3^{\circ}$. This material was used in accordance to the standards of the Ministry of Health and the National Health Council 196/96 Resolution. The study was approved by the institucional Ethics in
Human Research Committee (protocol \#127/2001).

The lateral cephalograms were separated by gender. Cephalometric tracings were performed on standard acetate paper $(17.5 \times 17.5 \mathrm{~cm}$ and $0.07 \mathrm{~mm}$ thickness) with a $0.3 \mathrm{~mm}$ graphite mechanical pencil, transparent ruler to the nearest $0.5 \mathrm{~mm}$, protractor to the nearest $0.1^{\circ}$, template, adhesive tape and illuminator. All tracings were done in a darkened room by the same investigator. The cranial and facial structures were outlined and then the investigator traced lines and planes to compose Jarabak's cephalometric analysis (Fig. 1).

Student's t-tes at 5\% significance level was used for data analysis (means, standard deviations, maximum and minimum values) and to assess gender differences.

Tracings were performed twice, with a minimum interval of 10 days, according to the method described by Midtgard et al. (15), aiming to eliminate possible investigator's error.

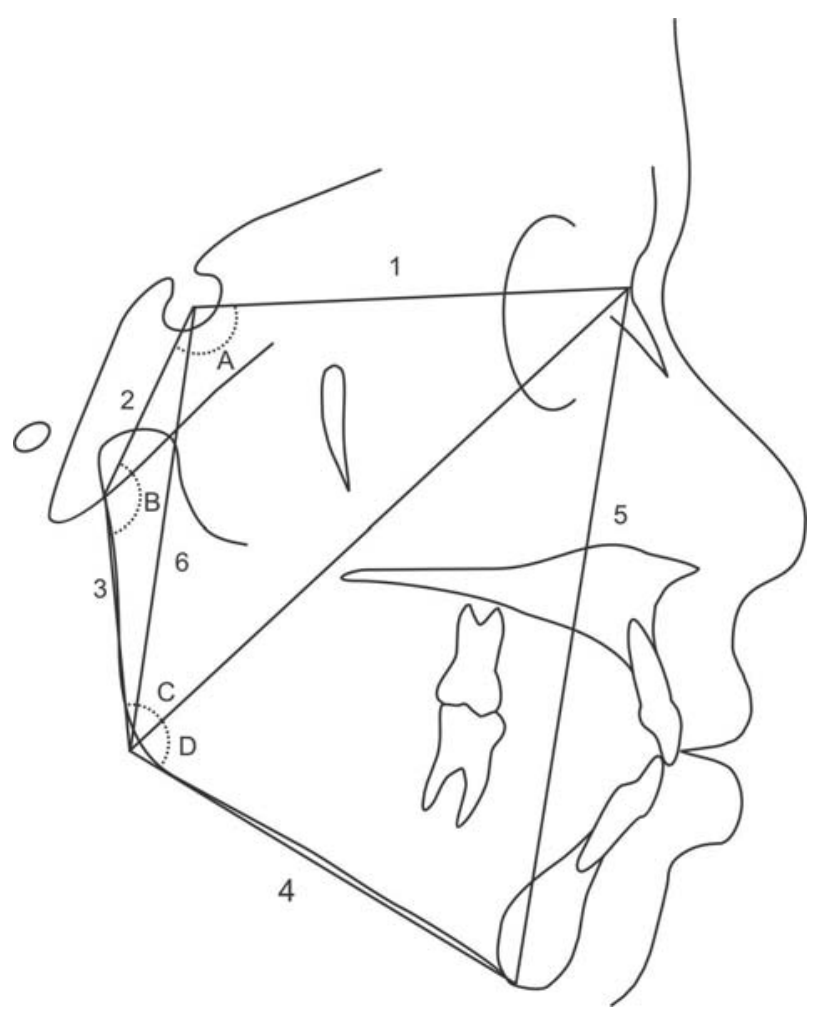

Figure 1. Measurements used for cephalometric analysis. Angular measurements: A. N-S-Ar (saddle angle); B. S-Ar-Goc (articular angle); C+D. Ar-Goc-Me (gonial angle); C. Ar-Goc-N (upper gonial angle); D. N-Goc-Me (lower gonial angle) and A+B+C+D. Ar-Goc-Me (sum of angles). Linear measurements: 1. S-N (anterior cranial base); 2. S-Ar (posterior cranial base); 3. Ar-Goc (ramus heigth); 4. Goc-Me (mandibular corpus); 5. N-Me (anterior facial heigth) and 6. S-Goc (posterior facial height). 


\section{RESULTS}

Statistical analysis of the cephalometric measurements obtained for the studied population showed no statistically significant differences between males and females (Table 1). Table 2 presents a comparison between the recorded cephalometric measurements and Jarabak's standards by gender. The cephalometric measurements calculated for the Black youngesters in this study were similar to Jarabak's standards, except for S-N mean value for female patients, which was significantly lower than the established Jarabak's standard.

\section{DISCUSSION}

The possibility to affect clinically the growth of facial structures is still a great challenge for dental practitioners who treat children, especially the orthodontists. The transformations that represent the change from child to adult are, in fact, the expression of growth. As growth is controlled by genetic, environmental and other general factors, it is expressed according to all these influences and thus, favorably or not, to the normal development of the face and occlusion. In

Table 1. Means ( \pm SD) of the cephalometric measurements obtained for both genders in the studied population.

\begin{tabular}{|c|c|c|c|c|}
\hline \multirow{2}{*}{$\begin{array}{l}\text { Cephalometric } \\
\text { measurements }\end{array}$} & \multicolumn{2}{|c|}{ Males } & \multicolumn{2}{|c|}{ Females } \\
\hline & Means & $\mathrm{SD}$ & Means & SD \\
\hline N-S-Ar $\left(^{\circ}\right)$ & $121.56 \mathrm{~A}$ & 6.91 & $124.38 \mathrm{~A}$ & 6.34 \\
\hline S-Ar-Goc $\left({ }^{\circ}\right)$ & $148.00 \mathrm{~A}$ & 8.21 & $144.88 \mathrm{~A}$ & 8.49 \\
\hline Ar-Goc-Me $\left({ }^{\circ}\right)$ & $122.19 \mathrm{~A}$ & 4.17 & $122.06 \mathrm{~A}$ & 5.40 \\
\hline $\mathrm{S}+\mathrm{Ar}+\mathrm{Go}\left(^{\circ}\right)$ & 391.75 A & 6.02 & $391.31 \mathrm{~A}$ & 4.81 \\
\hline Ar-Goc-N $\left(^{\circ}\right)$ & $50.63 \mathrm{~A}$ & 4.15 & $50.31 \mathrm{~A}$ & 5.31 \\
\hline N-Goc-Me $\left({ }^{\circ}\right)$ & $71.56 \mathrm{~A}$ & 4.82 & $71.75 \mathrm{~A}$ & 3.57 \\
\hline S-N (mm) & $68.44 \mathrm{~A}$ & 2.56 & $66.50 \mathrm{~A}$ & 3.16 \\
\hline Goc-Me (mm) & $73.25 \mathrm{~A}$ & 3.89 & $72.94 \mathrm{~A}$ & 3.07 \\
\hline $\mathrm{S}-\mathrm{Ar}(\mathrm{mm})$ & $33.56 \mathrm{~A}$ & 2.39 & 33.19 A & 3.17 \\
\hline Ar-Goc (mm) & $44.44 \mathrm{~A}$ & 4.52 & $44.50 \mathrm{~A}$ & 3.90 \\
\hline S-Goc (mm) & $74.81 \mathrm{~A}$ & 5.83 & $73.94 \mathrm{~A}$ & 3.70 \\
\hline $\mathrm{N}-\mathrm{Me}(\mathrm{mm})$ & 112.38 A & 7.46 & $111.94 \mathrm{~A}$ & 5.23 \\
\hline \% Jarabak & $66.83 \mathrm{~A}$ & 5.11 & $66.11 \mathrm{~A}$ & 3.03 \\
\hline
\end{tabular}

Same letters indicate no statistically significant difference at 5\% by Student's t-test. normal occlusion, jaws and other facial structures develop harmonically with successive growth alterations expressed mainly in the sagittal (anteroposterior and vertical) and transversal directions, especially guided in a sequence of events that result in an adult face with normal proportions and adequate occlusal relationships.

All cephalometric methods are related one or another way, differing only in their respective criteria for segmenting the dentocraniofacial complex, and having in common the measurements represented by different numerical values (1,3,1-17). Radiographic cephalometry has been used extensively to study facial form and to develop guidelines to aid in orthodontic diagnosis and treatment planning. It is also used to assess treatment progress and craniofacial growth, to predict growth for individual patients, and for other applications in orthodontic research (14). The patterns can be acceptably anticipated when combined to the Björk (2) analysis, while considering anterior and posterior cranial basis. Jarabak (1) associated morphological characteristics of the lower jaw with the other structures of the craniofacial complex.

When different ethnic groups are compared, one can observe skeletal and dental differences, and so there

Table 2. Comparison between the obtained cephalometric measurements and Jarabak's standards by gender.

\begin{tabular}{|c|c|c|c|c|}
\hline \multirow{2}{*}{$\begin{array}{l}\text { Cephalometric } \\
\text { measurements }\end{array}$} & \multicolumn{2}{|c|}{ Males } & \multicolumn{2}{|c|}{ Females } \\
\hline & Means & Jarabak’s & Means & Jarabak’s \\
\hline N-S-Ar $\left({ }^{\circ}\right)$ & 121.56 & $123 \pm 6$ & 124.38 & $123 \pm 6$ \\
\hline S-Ar-Goc $\left({ }^{\circ}\right)$ & 148.00 & $143 \pm 5$ & 144.88 & $143 \pm 5$ \\
\hline Ar-Goc-Me $\left(^{\circ}\right)$ & 122.19 & $130 \pm 7$ & 122.06 & $130 \pm 7$ \\
\hline $\mathrm{S}+\mathrm{Ar}+\mathrm{Go}\left({ }^{\circ}\right)$ & 391.75 & $396 \pm 6$ & 391.31 & $396 \pm 6$ \\
\hline Ar-Goc-N $\left({ }^{\circ}\right)$ & 50.63 & $52-55$ & 50.31 & $52-55$ \\
\hline N-Goc-Me $\left({ }^{\circ}\right)$ & 71.56 & $70-75$ & 71.75 & $70-75$ \\
\hline $\mathrm{S}-\mathrm{N}(\mathrm{mm})$ & 68.44 & $71 \pm 3$ & $66.50 *$ & $71 \pm 3^{*}$ \\
\hline Goc-Me (mm) & 73.25 & $71 \pm 5$ & 72.94 & $71 \pm 5$ \\
\hline $\mathrm{S}-\operatorname{Ar}(\mathrm{mm})$ & 33.56 & $32 \pm 3$ & 33.19 & $32 \pm 3$ \\
\hline $\operatorname{Ar}-\mathrm{Goc}(\mathrm{mm})$ & 44.44 & $44 \pm 5$ & 44.50 & $44 \pm 5$ \\
\hline S-Goc (mm) & 74.81 & $70-85$ & 73.94 & $70-85$ \\
\hline N-Me (mm) & 112.38 & $105-120$ & 111.94 & $105-120$ \\
\hline \% de Jarabak & 66.83 & $62-65 \%$ & 66.11 & $62-65 \%$ \\
\hline
\end{tabular}


is the need to evaluate cephalometric patterns and characteristics of the whole dentofacial complex individually for each group.

Cotton et al. (5) compared Blacks to three other ethnic groups. When compared to Caucasians, the Black individuals demonstrated a protrusion of maxilla, a convex profile, a steep mandibular plane and flared maxillary and mandibular incisors. Bialveolar protrusion, often referred to as bimaxillary protrusion, is a common occurrence in some ethnic groups because of the forward positioning of the teeth and its effect on the facial profile (12).

The cephalometric guidelines for the different ethnic and racial groups established in various studies show that normal measurements for one group are not necessarily normal for another group, which means that each racial group must be treated according to its own characteristics. A number of standards have been developed for the various racial and ethnic groups (57,9,14).

In the Table 1, it can be observed that the values obtained in this study were similar for both genders, as previously described by Gianelly (18). When Table 2 is examined, it can be noticed the obtained cephalometric measurements were correspondent to the standards stated by Jarabak. However, the anterior length of the cranial base, represented by S-N, presented a significantly lower mean value for female patients. These results were in agreement with those of Dandajena and Nanda (12), who reported that the anterior cranial base in Blacks is shorter than in Caucasians.

Several cephalometric studies (5-14) have stated that Black patients present different dental and skeletal characteristics from those of Caucasian patients. Nevertheless, in the present study, the values based on Caucasian cephalometric standards did not differ significantly from those obtained for a group of Brazilian Black youngsters. Acoording to these results, the following conclusions may be drawn: 1 . There was no differences between the genders; 2 . The cephalometric mean values recorded for the studied population were similar to Jarabak' standards, except for S-N in the female gender, which was significantly lower than the established standard.

\section{RESUMO}

A possibilidade de influenciar o crescimento das estruturas faciais continua sendo um grande desafio para os ortodontistas. As desarmonias esqueléticas apresentam melhores resultados se corrigidas no período de crescimento. As transformações ocorridas em um indivíduo representam a expressão do crescimento, que é regulado por fatores genéticos, gerais e ambientais. A fim de localizar as desarmonias, para concentrar as ações clínicas durante o tratamento e influenciar o crescimento facial, a cefalometria é um recurso diagnóstico útil na identificação do padrão facial ou na sua tendência de crescimento. A análise de Jarabak é utilizada para estudar o padrão de crescimento facial de indivíduos com oclusão normal ou com maloclusões. O objetivo do presente trabalho foi determinar os valores médios para as grandezas cefalométricas utilizadas na análise cefalométrica de Jarabak em indivíduos melanodermas, brasileiros, da região de Piracicaba, e com relação molar em Classe I com trespasse horizontal e vertical normal, com mínimo ou nenhum apinhamento ou diastemas e sem histórico de tratamento ortodôntico. Para tanto, foi utilizada uma amostra de 37 modelos de gesso pedra e 37 telerradiografias de cabeça, em norma lateral, de indivíduos de ambos os gêneros, compreendidos na faixa etária entre 10 a 14 anos. Os resultados foram submetidos ao teste "t" de Student, com nível de significância de 5\%. Não houve diferenças significantes entre os gêneros. As medidas encontradas na população estudada foram semelhantes ao padrão, diferindo somente o S-N para o gênero feminino, que foi de $66,50 \mathrm{~mm}( \pm 3,16)$, significantemente menor que a média padrão.

\section{REFERENCES}

1. Jarabak JR, Fizzel JA. Technique and treatment with light wire edgewise appliances. 2nd. ed. St. Louis: Mosby, 1972.

2. Björk A. Prediction of mandibular growth rotation. Am J Orthod 1969;55:585-599.

3. Björk A. Follow-up X-ray study of the individual variation in growth occurring between of 12 and 20 years and its relation to brain case and face development. Am J Orhod 1955;41:199-255.

4. Connor AM, Moshiri F. Orthognathic surgery norms for American black patients. Am J Orthod 1985;87:119-134.

5. Cotton WN, Takano WS, Wong WMW. The Downs analysis applied the three other ethnic groups. Angle Orthod 1951;21:213-220.

6. Kuramae M, Magnani MBBA, Nouer DF, Ambrosano GMB, Inoue RC. Analysis of Tweed's Facial Triangle in Black Brazilian youngsters with normal occlusion. Braz J Oral Sci 2004;8:401-403.

7. Flynn TR, Ambrogio RI, Zeichner SJ. Cephalometric norms for orthognathic surgery in black American adults. J Oral Maxillofac Surg 1989;47:30-39.

8. Naidoo LC, Miles LP. An evaluation of the mean cephalometric values for orthognathic surgery for black South African adults. Part 1: Hard tissue. J Dent Assoc S Afr 1997;52:495502.

9. Huang WJ, Taylor RW, Dasanayake AP. Determining cephalometric norms for Caucasians and African Americans in Birmingham. Angle Orthod 1998;68:503-511.

10. Bailey KL, Taylor RW. Mesh diagram cephalometric norms for Americans of African descent. Am J Orthod Dentofacial Orthop 1998;114:218-223.

11. Anderson AA, Anderson AC, Hornbuckle AC. Biological deri- 
vation of a range of cephalometric norms for children of African American descent (after Steiner). Am J Orthod Dentofacial Orthop 2000;118:90-100.

12 Dandajena TC, Nanda RS. Bialveolar protrusion in a Zimbabwean sample. Am J Orthod Dentofacial Orthop 2003;123:133-137.

13. Utomi IL. A cephalometric study of antero-posterior skeletal jaw relationship in Nigerian Hausa-Fulani children. West Afr J Med 2004;23:119-222.

14. Ajayi EO. Cephalometric norms of Nigerian children. Am J Orthod Dentofacial Orthop 2005;128:653-656.

15. Midtgard J, Björk G, Linder-Aronson S. Reproducibility of cephalometric landmarks and errors of measurements of cephalometric cranial distances. Angle Orthod 1974;44:5667.

16. Steiner CC. Cephalometrics for you and me. Am J Orthod 1953;39:729-755.

17. Tweed $\mathrm{CH}$. The Frankfort plane angle in orthodontics diagnosis, classification, treatment planning and prognosis. Am J Orthod \& Oral Surg 1946;34:175-230.

18. Gianelly AA. Age and sex cephalometric norms? Am J Orthod 1970;57:497-501.

Accepted September 4, 2006 